\title{
Are We There Yet! \\ Inclusion Of Higher Order Thinking Skills ( HOTs) in Assessment
}

\author{
Richa Mishra ${ }^{1}$, Ketan Kotecha ${ }^{2}$ \\ ${ }^{1}$ Department of Mathematics and Humanities, Institute of Technology, Nirma University, Ahmedabad, Gujarat \\ ${ }^{2}$ Provost, Parul University, Baroda, Gujarat \\ ${ }^{1}$ richa.mishra@nirmauni.ac.in \\ 22drketankotecha@gmail.com
}

\begin{abstract}
:
Mark Twain advice regarding not letting school interfering the education seems to be the order of the day. The students sitting in our classrooms are too different and demanding than previousdecades. These millennials demand life skills, real-life experiences, application oriented-ness and engagement that can help them in this very dynamic and robust workplace. The kerfuffle it has created in higher education is pushing the educators to experiment, reform and transform the whole education experience. One of the universities in western region has adopted the HOTs as the made for learning and assessing the students. The paper showcase this initiative which turned out to be simple yet forceful in creating an impact and thus transforming the nature of the learning - from Lower Order Thinking skills ( LOTs) to Higher Order Thinking Skills ( HOTs)
\end{abstract}

Keywords: assessment, LOTs, HOTs,

\section{Richa Mishra ${ }^{1}$}

${ }^{1}$ Department of Mathematics and Humanities, Institute of Technology, Nirma University, Ahmedabad, Gujarat ${ }^{1}$ richa.mishra@nirmauni.ac.in

\section{Preamble}

Higher education around the globe is on tenterhooks. The stakeholders understand the responsibility and conviction it needs to produce graduate who can not only earn money for a good life but also can provide societal support.

$21^{\text {st }}$ century has produced its own sets of problem. It has also given birth to new sets of desired skills that are needed for new kind of workspace and new emerging work profile. As indicated in P21's Framework for 21st Century Learning [1] which was envisioned by various stakeholders, skills needed for this century ranges from core subject to innovation, ICT skills to Life skills.

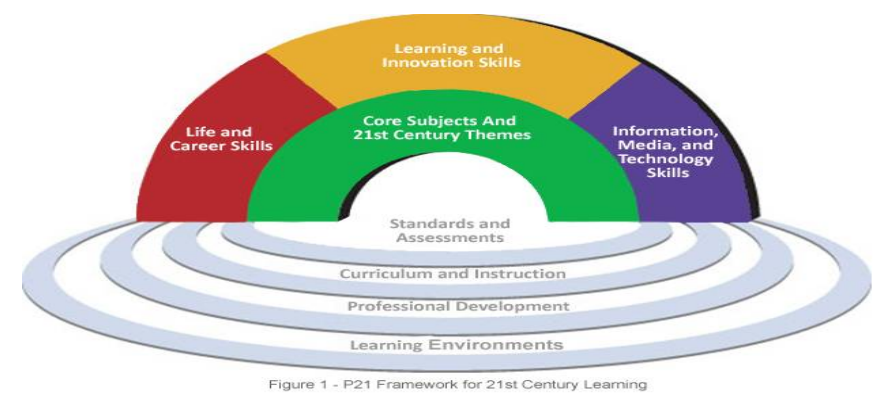

Fig 1-[Source: P21 framework for $21^{\text {st }}$ century Learning]

All this indicates that traditional system of input and output that is administering instructions/teaching in the class and then assessing the delivered lesson is not enough.

Recently a leading news paper reported the dismal figure of graduates coming out of the engineering colleges. The report indicated that between a fifth to a third of the million students run the risk of being unemployed [2] owing to their lack of required skills of $21^{\text {st }}$ century.Higher professional educations and other stakeholders are in constant pursue of the causes that are rising unemployable's rate among qualified students. The results are eye-opening. The much desired skills are soft skills 
including critical thinking, empathy, and integrity than hard skills. One survey (1999) charted employers' satisfaction for graduate'sprofessionexpertise which is desired by them for hiring. The expertise are categorized into four main factors, that is specific skills, core skills, personal characteristics, and communication skills under which skills like ethics, critical thinking, ability to adopt to changing technology and so on [3].

\begin{tabular}{llll}
\multicolumn{1}{c}{ Specific Skills } & \multicolumn{1}{c}{ Core Skills } & \multicolumn{1}{c}{$\begin{array}{c}\text { Personal } \\
\text { Characteristics }\end{array}$} & Communication Skills \\
\hline - Database kilowledge & - Self confidence & - Business ethics & - Listening skills \\
- Spreadsheet & - Critical thinking & - Professionalism & - Speaking skills \\
knowledge & - Creative thinking & & - Wiitten \\
- Word processing & - Interpersonal skills & communication \\
knowledge & - Leadership skills & \\
- Ability to adapt to & - Experience with real & & \\
changing teclinology & woild problems & & \\
- Technical skills & & & \\
- Mathematical skills & &
\end{tabular}

Fig. 2: Skills under four factors

In this same study which was done by World bank Employability and Skill Set of Newly Graduated Engineers in India done by Andreas Bloom, Hiroshi Saeki findings also highlighted the urgent need to develop the skill set of graduates which includes soft Skills; reflection upon assessments, teaching-learning process, and curricula away from lower-order thinking skills, such as remembering and understanding, toward higher-order skills along with problem solving, as well as creativity; and understanding the local needs and demand for skills in that region [4].

The same study also category further the specific skills needed by graduates. They are

\begin{tabular}{|c|c|c|}
\hline $\begin{array}{c}\text { Factor I } \\
\text { (Core Emplovability Skills) }\end{array}$ & $\begin{array}{c}\text { Factor? } \\
\text { (Professional Skills) }\end{array}$ & $\begin{array}{c}\text { Factors } \\
\text { (Communication Skills) }\end{array}$ \\
\hline I Integrity & - Identify, Gormulate, and solve & - Written communication \\
\hline - Self-discipline & Iectwicallenginering problems & - Desiggn \& conduct experiments, \\
\hline I Reliability & - Design a sssstem, component, or" & and analyze and interperet data \\
\hline - Self-motivated & process to meet desired needs & 1 Reading \\
\hline - Entreprenenurship Skills & - lsseappropritemodern tools, & - Communication in Enqughsh \\
\hline - Teamuork & enpipment, icthologies & - Technical Skills \\
\hline - Understands and takes & - Apply knowledge of mathematics, & - Veftal connmunication \\
\hline directions for work & science, enginering & - Basic compliter \\
\hline assiggnentits & - Cistomer Serice Skills & - Advanced computice \\
\hline - Wililingness to learn & - Knowledge of contemponary issules & \\
\hline - Flexiblitity & 1 Creativity & \\
\hline 1 Empathy & & \\
\hline
\end{tabular}

Fig 3.Importance of Levels by their usefulness

[Source: by World Bank Report - Employability and Skill Set of Newly Graduated Engineers in India)
The interesting and most decisive message from this finding can be that there is urgent need to include professional skills like identifying and solving problems, designing a product,process or an idea;applying knowledge and so on. That means a curriculum not only have HOTs in its curriculum but system should assure that HOTs are delivered also.

Many empirical research suggests that traditional education stress upon the lower order thinking skills ( LOTS ) and $21^{\text {st }}$ century workspace demands HOTS or Higher Order thinking Skills. (We have kept the Bloom's taxonomy as reference point to define LOTS and HOTS.)They can be represented as

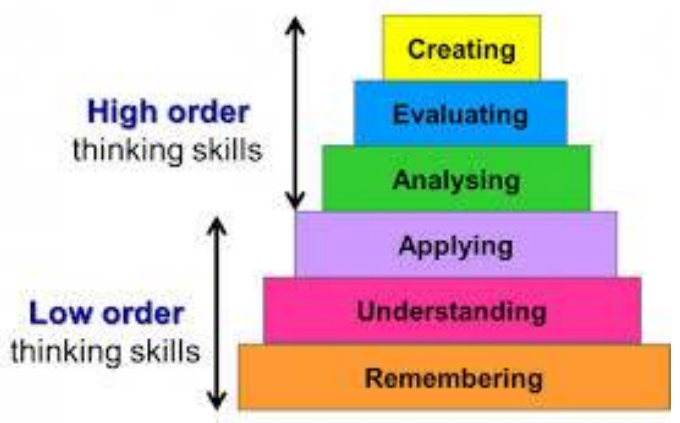

Fig.4. Blooms Taxonomy in Pyramid form.

(Source:

http://ateneu.xtec.cat/wikiform/wikiexport/_media/cmd/lle /clsi/modul_3/bloom_s_taxonomy.png?w=500\&tok=3d82 04)

This lead to the problem of defining and assessing HOTS.

\section{Solution}

Higher-order thinking skills can be divided into three categories: (1) in terms of transfer, (2) in terms of critical thinking, and (3) in terms of problem solving[5 ]. Transfer means retention of knowledge and then transferring into real life means HOTs.

Critical thinking means logical, contemplative thinking which is that is fixated on deciding what to believe or do [6]. It includes skills which teach students- ability to distinguish between not credible and credible source, delineate assumptions, categorisation and bias; understand the content and motive of the text, able to analyse, judge and evaluate.

Problem solving includes remembering information, understanding the learning and then, critically assessingconcepts, framinginnovativeoptions, and articulating them[7].

Various initiatives were taken across the globe to teach HOTs deductively and it was reported that when teachers were taught and told explicitly about use of HOTs and then was later informed to students about their expectations and 
given direct instructions, it has raised the skills sets. [8]

\section{Assurance of Learning}

How to get assurance of learning,is a major issue rightnow. In universities students were assessed either by students reporting through their works like assignments, reports, projects and journals or by faculty members administering tests.[9] Adopting Outcome Based Education around the globe was one of the solution where learning was judged in continual basis by rubrics and other direct and indirect methods, but heavy documentation and system dependence on collecting the data has somehow made the vary system which promises to bring reformation stifling the process. In a country like India, massification of education and large classrooms [10] is one of the biggest challenges to OBE model. Taking all these factors in sight, one of the premier universities in western region of India, decided to adopt a different tactic.

It was decided to sensitize teachers for HOTs and make them deliver courses accordingly and then to map the Question paper using bloom's taxonomy so as to see how much HOTs were incorporated in the test paper.

This paper showcases the assessment of the HOTs through Semester End Examinations and evidence of the same.

\section{The strategy}

With the aim to shift the paradigm from LOTs to HOTs (bottom of the pyramid to top of the pyramid). The need is to encourage the Higher Order Thinking Skills in the students so that they can analyse, evaluate, predict, synthesise and create solutions for the real life problem.

The irony of the university teachers are that they are trained researchers but not trained educators. Realizing this, the university started with sensitizing the faculty members towards inclusion of instructional content as well as assessment oriented towards HOTs. Teachers were sensitizesufficiently about the same.

This ensuredthe holistic inclusion which ensured students getting administered having Higher Order Thinking Skillsdeductively and inductively.

The objectives of the initiatives were:

1. To move the teaching-learning process towards Higher Order Thinking Skills.

2. Tangible intervention through workshops/lectures and seminar on HOTS and methodology to achieve it.

3. To sensitize faculty members and break the traditional mind-set.

4. To produce graduates with HOTS having capability to deal with complex real life problems and design solutions.

The initiative began by handpicking the faculty membersfrom an engineering college of the university and then conducting various workshops and lectures related with Bloom's Taxonomy, HOTs and Critical thinking for them.

Sessions on how to include HOTs in question paper was also made. Teachers were made aware of Blooms taxonomy verbs and were asked to use them in designing the Course Learning Outcome ( CLOs) and question papers.

This study was conducted as a part of minor research grant funded by the University.

The after-intervention was done with the sample size of 40 senior faculty members of institute of Technology which is considerably a good size. The participants of the study are from different demography and most of them have doctorate degrees. They all are teaching for more than 5 years or so.

The method employed was used as:

1.They have been asked to bring the test papers drawn by them and fill up the survey powered by survey monkey.

2. It was found that the question papers were mostly evaluating LOTs as in the class as it was emphasized about.

3.After the workshop, sensitization and rigorous followups the same faculty members for the same subject drew the question paper for semester end examination.

4.Again they were informed to participate in the same survey (they were not having prior information about this post intervention survey.)

\section{WORKSHEET AFTER INTERVENTION}

Course Name:

Course Code:

Mapping of SEEASEESE paper with Blooms Taxonomy

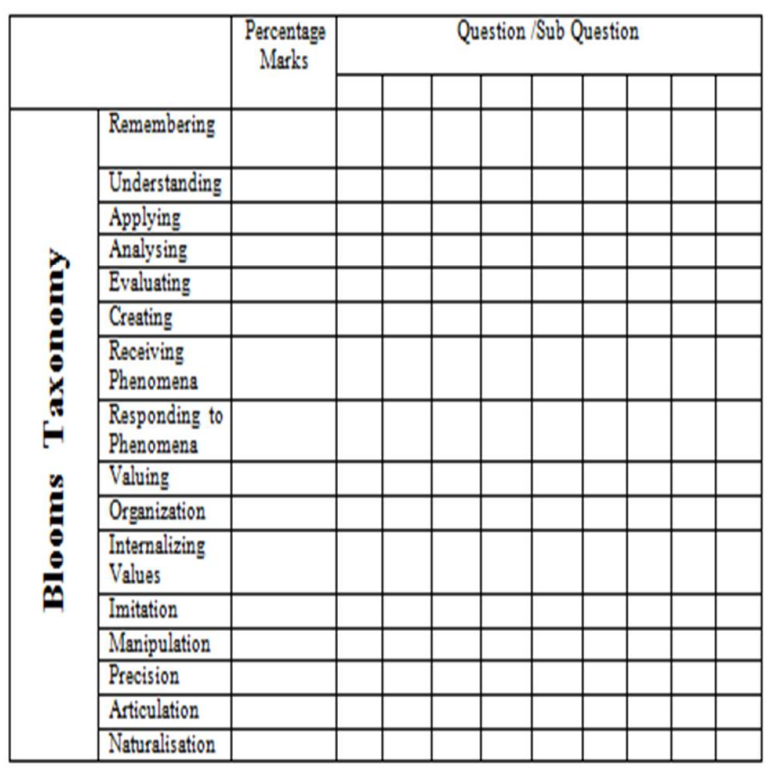

Fig: worksheet (pre and post intervention) 
The results were analysed and we found major shift from LOTS to HOTS which is depicted in the graph below:

\section{Pre/Post design of Question Papers}

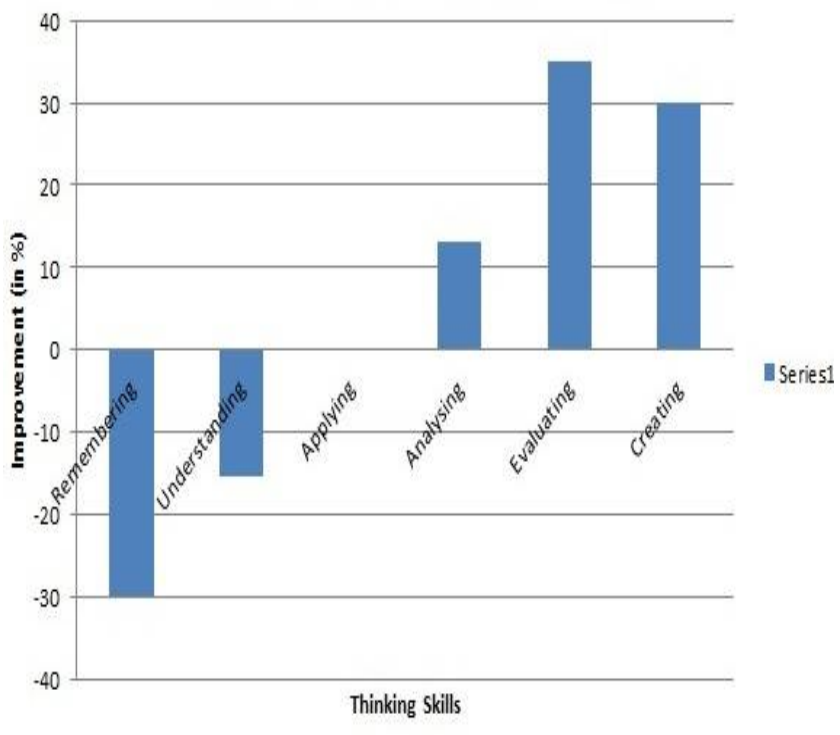

Fig: Graph indicates pre and post intervention shift from LOTs to HOTs.

\section{Conclusion}

As Albert Einstein has said - make it simple. The results are impactful, powerful and yet very simple to get. A change in attitude, learning -method transformation and assessment -method sensitization can turn the tables. The learningstudents get getting turned from LOTs and HOTs simply by sensitizing the faculty members. It is recommended that university should attempt to add more programmes, workshops related with the education as well for their faculty members. The onus is upon the faculty members to turn the classroom teaching into learning that will encompass $21^{\text {st }}$ century skills.

\section{Future Scope:}

By realising the problem of lack of HOTS in classroom and HOTs evaluation in test paper, based on few more random survey of question papers of some other institute belonging to other universities, it was observed that most of the question papers were structured only to evaluate LOTS. The authors are receipt of Minor Research Grant from their university and they have taken five different colleges under different universities to replace the result. The project is going on.

\section{Reference:}

[1] http://www.p21.org/our-work/p21-framework
[2] http://articles.economictimes.indiatimes.com/201306-18/news/40049243_1_engineers-iit-bombay-batchsize

[3] Paranto, Sharon R., MayureshKelker (1999), Employer Satisfaction with Job Skills of Business College Graduates and Its Impact on Hiring Behavior, Journal of Marketing for Higher Education, Vol. 9(3), The Haworth Press, Inc., New York, USA.( Fig 2)

[4] Blom, Andreas; Saeki, Hiroshi. 2011. Employability and skill set of newly graduated engineers in India. Policy Research working paper ; no. WPS 5640. Washington, DC: World bank http://documents.worldbank.org/curated/en/2011/04/1 4103800/employability-skill-set-newly-graduatedengineers-india

[5] Brookhart, S. (2010), How to Assess Higher Order Thinking Skills in Your Classroom, ASCD, http://www.ascd.org/Publications/Books/Overview/Ho w-to-Assess-Higher-Order-Thinking-Skills-in-YourClassroom.aspx

[6] Norris, S. \& Ennis, R. (1989), Evaluating Critical Thinking, Pacific Grove, CA: Midwest Publications

[7] Hattie, J. (2009), Visible Learning: a Synthesis of Over 800 Meta-Analyses Relating to Achievement, Oxon, OX: Routledge

[8] Barahal, S. (2008), Thinking about Thinking: PreService Teachers Strengthen their Thinking Artfully, Phi Delta Kappan 90 (4)

[9] MISHRA, Richa; KOTECHA, K.. Defining Learning Outcomes of Co-Curricular Activities: Integrating Desired Commonalities. Journal of Engineering Education Transformations, [S.1.], p. 286-291, jan. 2015. ISSN 2394-1707. Available at: $<$ http://journaleet.org/index.php/jeet/article/view/5935 8>. Date accessed: 30 Mar. 2015. doi:10.16920/ijerit/2015/v0i0/59358.

[10]R Mishra, K Kotecha,(2012). Teaching Communication Skills Student Engagement Through Blogging'International Journal of Humanities and Social Sciences (IJHSS) 2 (2), 4 